\author{
Проф. др ВЛАДИСЛАВ ПУЗОВИЋ \\ Универзитет у Београду \\ Православни богословски факултет \\ Мије Ковачевића 11б, Београд, Србија \\ Е-адреса: vpuzovic@bfspc.bg.ac.rs
}

\title{
О ДОКТОРСКОЈ ДИСЕРТАЦИЈИ ЂОКА СЛИЈЕПЧЕВИЋА
}

САЖЕТАК: У раду се представља прва докторска дисертација одбрањена на Православном богословском факултету у Београду 1936. године, чији је аутор био један од најистакнутијих српских црквених историчара XX века - Ђоко Слијепчевић. Дисертација је посвећена лику и делу митрополита карловачког Стефана Стратимировића. Рад представља научни контекст настанка дисертације, њен садржај, процедуру њене одбране и њену рецепцију у српској историографији. Циљ рада је указивање на значај овог дела у историји српске историографије као прве свеобухватне и систематске монографије о знаменитом карловачком митрополиту, која ни данас није изгубила научну референтност.

КљУЧНЕ РЕЧИ: Ђоко Слијепчевић, Православни богословски факултет у Београду, докторска дисертација, митрополит Стефан Стратимировић, Стеван Димитријевић, српска историографија

Ђоко Слијепчевић, ${ }^{1}$ један од најзначајнијих српских црквених историчара XX века, докторирао је на Православном богословском факултету у

1 Референтна библиографија о Ђоку Слијепчевићу: П. Пузовић, „Др Ђоко Слијепчевић (1907-1993) - Биографија и библиографија”, Боіословље 1-2 (1992), 103-116; Д. Калезић, „Историја Цркве у радовима Ђока Слијепчевића”, Срйска йроза gанас: Перо и Ђоко Слијейчевић-животи и gјело, прир. Р. Братић, Београд 1998, 155-160; П. Пузовић, „Сећање на Ђоку Слијепчевића”, Боіословље 2 (2002), 275-278; Р. Поповић, „Др Ђоко Слијепчевић - историчар Српске Православне Цркве”, Бойословље 2 (2002), 269-274; Н. Андријашевић, „Објављивање чланака проф. др Ђока Слијепчевића у Јужноафричкој Републици”, Бог̆ословље 2 (2018), $110-125 ;$ Н. Андријашевић, „О животу и раду Ђока Слијепчевића са библиографијом његових радова до 1944”, Симйлексис 1 (2018), 61-79; Н. Андријашевић, „Рад проф. др Ђока Слијепчевића у Институту за југоисточну Европу (Südosteuropa Institut) у Минхену 1955 1975”, Токови истиорије 1 (2019), 111-144; Н. Андријашевић, „Професор др Ђоко Слијепчевић у Швајцарској 1948-1954”, Црквене стиуяquје 2 (2019), 359-378; Н. Андријашевић, „Живот и рад проф. др Ђока Слијепчевића у Савезној Републици Немачкој 1954-1993”, Боїословље 1 
Београду, 1936. године. ${ }^{2}$ Његова докторска дисертација била је посвећена лику и делу митрополита карловачког Стефана Стратимировића. Ова дисертација била је прва систематска и свеобухватна студија монографског карактера посвећена овој значајној личности српске црквене историје, која је готово пола века била на челу Карловачке митрополије. Појава ове дисертације представљала је важан научни догађај, о чему сведочи значајна пажња која јој је била посвећена у српској научној заједници. Приказе и осврте на ову дисертацију писали су тадашњи најзначајнији српски историчари.

\section{СРПСКА ИСТОРИОГРАФИЈА О МИТРОПОЛИТУ СТРАТИМИРОВИЋУ ПРЕ СЛИЈЕПЧЕВИЋЕВЕ ДИСЕРТАЦИЈЕ}

Пишући одредницу о митрополиту Стефану Стратимировићу, која се 1929. године појавила у Станојевићевој Нарояној енцзиклойеgији, Радослав Грујић је констатовао да овај значајни српски архијереј „нема још биографије”. ${ }^{3}$ Исте године сличан исказ поновио је и Никола Радојчић: „Има веома мало тако једнодушних жеља у нашој науци као што је жудња за једном монографијом о Стефану Стратимировићу.”4 Дотадашњи озбиљни научни радови посвећени карловачком митрополиту Стефану Стратимировићу били су малобројни и најчешће су захватали само одређене појединости његове вишеслојне делатности. Његове улоге у развоју српске црквене просвете дотакао се 1886. године Иларион Руварац у раду посвећеном питању отварања семинарије за свештеничке кандидате у Карловачкој митрополији. ${ }^{5}$ Његовом епистоларном наслеђу пажњу је посветио Радослав Грујић 1908. године. ${ }^{6}$ Већина текстова о митрополиту Стефану Стратимировићу, објављиваних у црквеним часописима у Карловачкој митрополији у периоду до Првог светског рата, били су пригодног и панегиричног карактера.

После Првог светског рата повећана је научна пажња према личности и делу митрополита Стефана Стратимировића. Димитрије Руварац припремио је за штампу студију о митрополитовом животу и раду, али она није прошла рецензију за објављивање у издању Српске краљевске академије. 7 Уместо тога објавио је „Нацрт живота и списак књижевних радова Митрополита

(2020), 97-127; В. Пузовић, „Путеви српске црквеноисторијске науке: српски богослови као истраживачи историје Српске Цркве”, Осам векова ауйокефалије Срйске Православне Цркве, II, ур. В. Пузовић и В. Таталовић, Београд 2020, 95-120.

2 Слијепчевићева докторска дисертација била је прва одбрањена докторска дисертација на београдском Православном богословском факултету.

${ }^{3}$ R. Grujić, ,Stratimirović Stefan”, Narodna enciklopedija srpsko-hrvatsko-slovenačka, knj. IV, Zagreb 1929, 516.

${ }^{4}$ Н. Радојчић, „Историјске студије митрополита Стефана Стратимировића”, Гласник

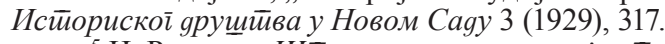

${ }^{5}$ И. Руварац, Шйа се и како се и с које ситране досле иокущавало gа се и коg нас оснује Семинарија за каняияайе свешитеничкой реgа, Нови Сад 1886.

6 Р. Грујић, „Књижевна писма митрополита Стевана Стратимировића”, Бойословски іласник 3-4 (1908), 204-219; 5-6 (1908), 311-324.

7 Овај податак изнео је Јован Радонић, сведочећи да је имао прилику да прочита поменуту непубликовану Руварчеву студију, која је била „слабо компонована и с осетним празнинама, није ни мало одговарала очекивањима стручњака и поштоваоцима знаменитог 
Стевана Стратимировића" у Прилозима професора Павла Поповића, 1921. године. ${ }^{8}$ Пет година касније у првом броју Боіословљ $a$ појавила се студија Стевана Димитријевића посвећена митрополитовом мемоару о ослобођењу српског народа упућеном руском цару Александру I. ${ }^{9}$ Уследили су 1929 . године енциклопедијска одредница Радослава Грујића ${ }^{10}$ и рад Николе Радојчића посвећен митрополитовим историографским настојањима. ${ }^{11}$ Две године касније Димитрије Руварац објавио је још један рад о митрополиту Стратимировићу, заокружујући своја дотадашња истраживања о њему. ${ }^{12}$ На Савиндан 1936. године, на свечаном скупу у Матици српској, говор посвећен Стратимировићу, а поводом стогодишњице његовог упокојења, изнео је Никола Радојчић. ${ }^{13}$ У њему није преовладавао панегиричан тон, иако је био изнет свечаним поводом. Био је то објективан научни поглед са избалансираним оценама, у оквиру којег су представљени и анализирани главни аспекти Стратимировићевог просветног, националног и књижевног рада. Била је то својеврсна схема за научну монографију о митрополиту. Неколико месеци касније појавила се докторска дисертација Ђока Слијепчевића посвећена митрополиту Стефану Стратимировићу.

\section{Докторска дисертација Ђока Слијепчевића}

Подстицај за писање дисертације о митрополиту Стефану Стратимировићу Ђоко Слијепчевић добио је од проте Стевана Димитријевића, првог професора Историје Српске православне цркве на Православном богословском факултету. О томе је сведочио у једном каснијем чланку посвећеном свом ментору: „Своје интересовање за митрополита Стратимировића Димитријевић је пренео и на писца овог састава и препоручио му за докторски рад

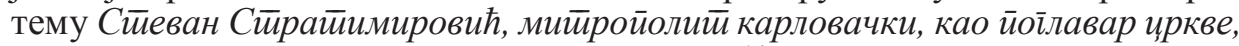

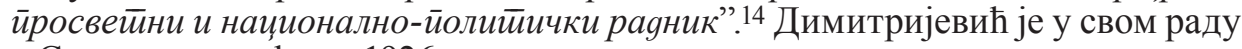
о Стратимировићу из 1926. године истакао да изучавање и потпуно приказивање митрополитовог живота и рада треба да буде „предмет опширног и свестраног истраживања". ${ }^{15}$ Погодног кандидата за такво истраживање пронашао

митрополита”. Ј. Радонић, „Ђоко М. Слијепчевић, Стеван Стратимировић, Београд 1936”, Јуїословенски исӣориски часойис 1-4 (1937), 386.

8 Д. Руварац, „Нацрт живота и списак књижевних радова Митрополита Стевана Стра-

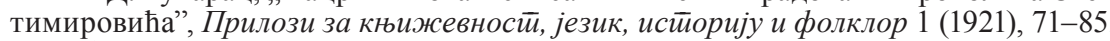

9 С. Димитријевић, „Стевана Стратимировића, митрополита карловачког, план за ослобођење српског народа”, Боїословље 1 (1926), 38-66.

10 R. Grujić, „Stratimirović Stefan”, Narodna enciklopedija srpsko-hrvatsko-slovenačka, knj. IV, Zagreb 1929, 515-516.

${ }^{11}$ Н. Радојчић, „Историјске студије митрополита Стефана Стратимировића”, Гласник Исӣориской ярущиивва у Новом Саяу 3 (1929), 317-364.

12 Д. Руварац, „Митрополит Стеван Стратимировић”, Гласник Исӣориской gрущйвва у Новом Саgу 3 (1931), 374-391.

${ }_{13}$ Радојчићев говор је објављен у Лет̄ойису Майице срӣске: Н. Радојчић, „Митрополит Стефан Стратимировић”, Лейойис Майище срйске 1 (1936), 40-60.

14 Ђ. Слијепчевић, „Национални и научни лик Стевана М. Димитријевића”, Искра 656-657 (1978), 11.

${ }^{15}$ С. Димитријевић, „Стевана Стратимировића, митрополита карловачког, план за ослобођење српског народа”, Боїословље 1 (1926), 66. 
је у дипломираном студенту Православног богословског факултета и супленту Четврте мушке реалне гимназије у Београду, Ђоку Слијепчевићу. Димитријевићу су добро биле познате научне способности Слијепчевића као и његов интерес за српску црквену историју који је пројављивао током студирања. Током сваке академске године Слијепчевић је писао по један темат из српске црквене историје и сваки је био награђен. ${ }^{16}$ Посебно је била важна озбиљна научна студија посвећена патријарху Пајсију Јањевцу, ${ }^{17}$ која је у многим аспектима представљала пионирски подухват у научном проучавању лика и дела овог српског патријарха из XVII века. Темат који је настао током четврте године студија (1933/1934), посвећен митрополиту Стефану Стратимировићу, био је својеврстан увод у његово дубље проучавање делатности овог архијереја које ће неколико година касније резултирати докторском дисертацијом. У српској богословској јавности Слијепчевић је био познат као један од покретача богословских научних часописа Светеиосавље, Хрищћанска мисао и $\Pi y \bar{u}$, као и аутор већег броја чланака углавном у поменутим часописима који су били посвећени црквеноисторијским и актуелним црквеним темама..$^{18}$

Докторска дисертација Ђока Слијепчевића под насловом Митиройолий

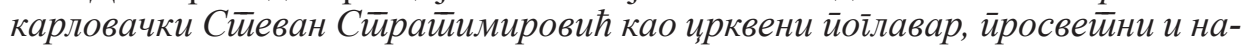
ционално-йолитиччки раяеник написана је на 284 странице машинописа, уз још 10 уводних страница обележених римским бројевима и две последње странице посвећене садржају. ${ }^{19}$ Коришћена је архивска грађа из четири архивска фонда. Главнину коришћених извора чинили су материјали из Митрополијско-народног црквеног архива у Сремским Карловцима. Коришћена је грађа из Архива Српске краљевске академије у Београду, Државног архива у Београду, као и необјављена писма из фондова Народне библиотеке у Београду. У уводу дисертације Слијепчевић је истакао да је у поменутим фондовима „прегледао сву архивску грађу”, као и да је „прегледао сву архивску

16 Током прве године студија Слијепчевић је написао рад на тему Незаконийости уки-

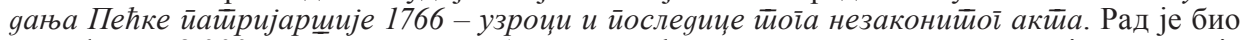
награђен са 2.000 динара из Фонда Алексе Илића. Током друге године студија написао је рад из опште црквене историје на тему Пайсииво и васељенски сабори. Рад је наградила београдска Саборна црква. Током треће године студија написао је рад на тему Пајсије архиейиской йећки и йайријарх срйски као јерарх и књижевни раяник. За овај рад добио је награду Његовог Величанства краља Александра I Карађорђевића. Рад је био објављен у факултетском научном часопису Боїословље. Током четврте године студија написао је рад на тему

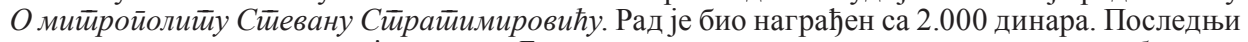
студентски темат написао је на тему Беоіраgска митиройолија и мийройолийи оg обновљења Пећке йайријарщије gо њеної йрисајеgињења Цариіраяској (1557-1766). Рад је добио награду Београдске општине у износу од 2.000 динара (Архив Православног богословског факултета Универзитета у Београду (даље: Архив ПБФ), Професорски gосије Ђока М. Слијейчевића).

17 Ђ. Слијепчевић, „Пајсије, архиепископ пећки и патријарх српски као јерарх и књижевни радник”, Бойословље 2 (1933), 123-144; 3 (1933), 241-283.

18 Детаљније о научној делатности Ђока Слијепчевића, у поменутом периоду: Н. Андријашевић, „О животу и раду Ђока Слијепчевића са библиографијом његових радова до 1944”, Симйлексис 1 (2018), 61-79.

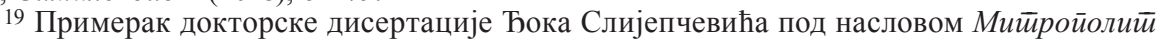

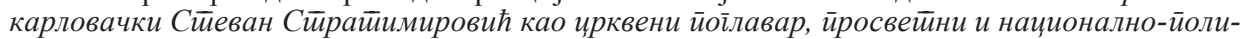

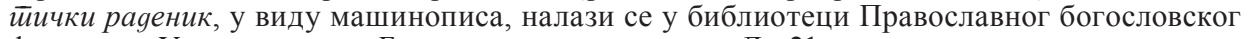
факултета Универзитета у Београду, под сигнатуром Др-21. 
грађу која је објављена или посебно или разбацана по разним часописима". Као недостатак навео је изостанак руске архивске грађе до које „није било могуће доћи". ${ }^{20}$ Слијепчевић је употребио радове из 22 часописа, док се у списку коришћене литературе налази 86 научних радова. Аутор са највећим бројем радова у поменутом списку био је Димитрије Руварац (7 радова). У овом списку, између осталих, налазили су се радови Николе Радојчића, Стевана Димитријевића, Миленка Вукићевића, Манојла Грбића, Димитрија Кириловића, Јована Радонића, Мите Костића, Станоја Станојевића, Јована Суботића, Јована Скерлића.

Структуру Слијепчевићеве дисертације чине три централна поглавља уз уводне делове и закључак. Дисертација почиње уводом у којем су представљене тема и циљ дисертације, њена структура, коришћени извори и литеpaтура (I-IV). Следи списак коришћене библиографије (V-X), а затим поглавље уводног карактера под насловом Биоірафски йоgаци о мийройолийу

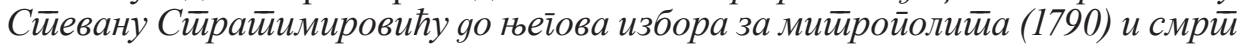
(1-21). Прво од три централна поглавља носи наслов Црквени pag митиройо-

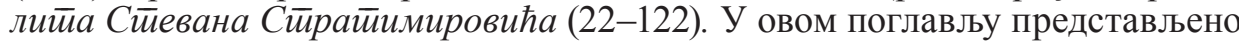
је Стратимировићево старање о материјалном обезбеђењу и васпитном подизању свештенства, обнови монаштва, занављању епископата, борби против унијаћења, увођења новог календара и увођења световних лица у конзисто-

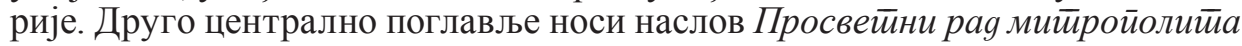

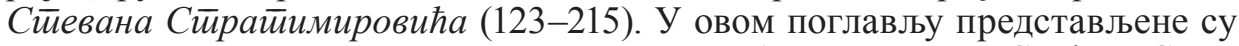
школске и културно-просветне прилике пре доба митрополита Стефана Стратимировића, његов рад на унапређењу основних и средњих школа, залагање за штампарију, његов однос према Вуку Караџићу. Треће централно погла-

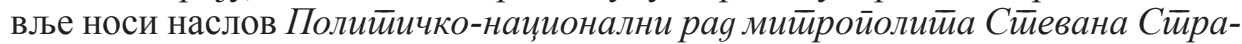
ииимировића (216-281). У оквиру овог поглавља обрађени су политичка интересовања и рад митрополита у контексту његовог мемоара упућеног руском цару Александру I, његова улога у Првом српском устанку, његов однос према Тицановој и Белоцркванској буни, његов однос према кнезу Милошу. Дисертација је завршена кратким закључком (282-284).

Приликом писања дисертације Слијепчевић се суочио са сложеном темом која је у дотадашњој литератури била само делимично дотакнута. Одабрао је три крупне целине многостране делатности митрополита Стефана Стратимировића, док је једну свесно изоставио. Радило се о књижевном и научном митрополитовом раду. Његов црквени, просветни и политичко-национални рад представио је првенствено се ослањајући на архивску грађу. Слијепчевић је судове о Стратимировићу формирао трудећи се да схвати дух преломне епохе, који је доносио многе културне, духовне и политичке промене српском народу. Поредећи његове судове са судовима дотадашњих истраживача митрополитовог рада, а посебно судовима Јована Скерлића и Димитрија Руварца, може се констатовати да се Слијепчевић трудио да коригује преовлађујући критички тон у односу на Стратимировића.

Ђоко Слијепчевић је пријаву за полагање докторског испита, уз пет примерака докторске дисертације, предао декану Православног богословског

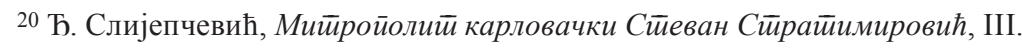


факултета Лазару Мирковићу, 17. априла 1936. године. У пријави је навео да је дисертацију написао „у споразуму са господином Стеваном Димитријевићем, редовним професором Универзитета". ${ }^{21}$ Савет факултета је на седници одржаној 22. априла исте године одредио комисију за полагање докторског испита. ${ }^{22}$ Слијепчевићев усмени део докторског испита, који је уједно био први у историји Православног богословског факултета, одржан је 22. јуна 1936. године. Одговарао је на питања из Опште историје Цркве, Историје Српске цркве и Патрологије. ${ }^{23}$ Наредног дана професори Стеван Димитријевић и Филарет Гранић поднели су комисији за одбрану Слијепчевићеве дисертације кратак реферат о самој дисертацији. Примедбе у реферату односиле су се на распоред одређених одељака у дисертацији, као и на непотребно велики обим одељка из другог централног поглавља, који је био посвећен културно-просветним приликама пре доба митрополита Стефана Стратимировића. Дисертација је похваљена као „резултат једног добро смишљеног и са ретком марљивошћу и великим напором написаног научног дела". Као једну од главних вредности рада референти су истакли добро коришћење обимне необјављене архивске грађе. Реферат су завршили констатацијом да је кандидат показао да „потпуно влада научним методом и да је способан да самостално ради на науци". ${ }^{24}$ Усмена одбрана дисертације уследила је 29. јуна и трајала је од 8.15 до 9.15 часова преподне. Пред комисијом којом је председавао професор Лазар Мирковић, а коју су још чинили професори Стеван Димитријевић, Драгутин Анастасијевић, Филарет Гранић и Александар Павлович Доброклонски, Ђоко Слијепчевић успешно је одбранио своју докторску дисертацију. ${ }^{25}$ Диплому доктора богословских наука (бр. 3758, од 16. октобра 1936. године), коју су потписали ректор Београдског универзитета Драгослав Јовановић и декан Православног богословског факултета Димитрије Стефановић, Слијепчевић је примио на свечаној промоцији, 14. децембра 1936. године. ${ }^{26}$

\section{РЕЦЕПЦИЈА СЛИЈЕПЧЕВИЋЕВЕ ДИСЕРТАЦИЈЕ У СРПСКОЈ ИСТОРИОГРАФИЈИ}

У летњем броју Хрищћанске мисли (за јул и август 1936. године) најављено је публиковање докторске дисертације Ђока Слијепчевића за септембар исте године. Најављена је као „изузетан, крупан прилог нашој историографији, а посредно нашој културној и политичкој мисли". ${ }^{27}$ Дисертација се

${ }^{21}$ Архив ПБФ, Професорски досије Бока М. Слијейчевића.

22 Комисију су чинили следећи професори: Лазар Мирковић, Стеван Димитријевић, Драгутин Анастасијевић, Филарет Гранић и Александар Павлович Доброклонски. За референте су одређени Димитријевић и Гранић (Архив ПБФ, Зайисник сеgний Савет̄а Пра-

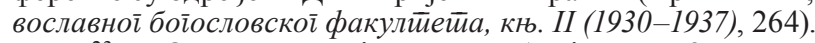

${ }^{23}$ Из Опште историје Цркве добио је оцену 9, из Историје Српске цркве оцену 8, а из Патрологије оцену 9 (Архив ПБФ, Професорски досије Бока М. Слијейчевића).

${ }^{24}$ Исто.

25 Исто.

${ }^{26}$ Ието.

27 „Ђоко Слијепчевић: Стеван Стратимировић, митрополит карловачки”, Хрищћанска мисао 7-8 (1936), 120. 
појавила као монографија, у издању београдске књижаре Владе Н. Рајковића. ${ }^{28}$ Објављивање монографије било је пропраћено Слијепчевићевим текстом посвећеним митрополиту Стефану Стратимировићу у дневном листу Правgа. ${ }^{29}$ У овом тексту сажето је представио кључне аспекте делатности митрополита и своју књигу најавио као исправљање неправде према њему, због стогодишњег запостављања и необјективног приказивања. ${ }^{30}$ Појава Слијепчевићеве монографије изазвала је значајну пажњу српске научне јавности. Први прикази појавили су се већ крајем 1936. године, а прикази и студије подстакнуте Слијепчевићевим делом објављивани су током 1937. године и касније. У научну расправу о Слијепчевићевом делу били су укључени водећи српски историчари међуратног периода.

Крајем 1936. године појавила су се два приказа монографије посвећене митрополиту Стефану Стратимировићу. Станоје Станојевић објавио је при-

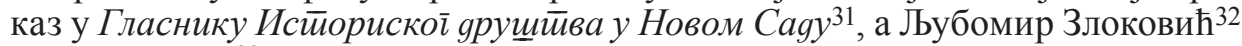
у Светиосављу ${ }^{33}$. Станојевић је Слијепчевићеву књигу видео као попуњавање „једне велике празнине, која се у нашој историографији јако осећала”. ${ }^{44}$ Похвалио је аутора за исцрпно коришћење домаћих извора, али и напоменуо да би рад био потпунији да су коришћени бечки извори. Као најбољи део рада оценио је прво централно поглавље посвећено црквеном раду митрополита, а као најслабије оно посвећено његовом политичко-националном раду. Истакао је да ће се „у детаљима о ономе што је изнео г. Слијепчевић у својој књизи, без сумње много што шта моћи допунити, исправљати се свакако неће имати много". 35 Станојевићу се није допао Слијепчевићев апологетски тон према митрополиту, који је по њему понекад био претеран, и који је отежавао да се после читања књиге створи јаснији суд о делатности овог архијереја.

У Злоковићевом приказу није било критичких тонова према Слијепчевићевом делу, већ искључиво похвале. Истакао је, као и Станојевић, да је овај рад попунио празнину у српској историографији. Похвално је писао о коришћеној архивској грађи, инсистирајући на томе да је писац „дао све што је могао дати; све оно са чиме су располагали наши архиви и наше библиотеке, он је савесно искористио". ${ }^{36}$ За разлику од Станојевића Злоковић је сматрао да је Слијепчевић успео да коригује дотадашње критичке судове о митро-

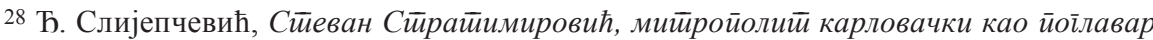

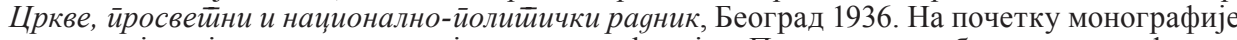
наведено је да је реч о докторској тези прихваћеној на Православном богословском факултету, на основу реферата професора Стевана Димитријевића и Филарета Гранића.

29 Ђ. Слијепчевић, „После сто година. Један национални великан добио је признање Живот и дела Стевана Стратимировића", Правgа 11.466 (24. септембра 1936), 6-7.

30 Исто, 7.

31 С. Станојевић, „Ђоко М. Слијепчевић, Стеван Стратимировић, Београд, 1936”, Гласник Истиориской друщйвва у Новом Саgу 4 (1936), 470-471.

32 Злоковић је у време објављивања поменутог приказа био студент Православног

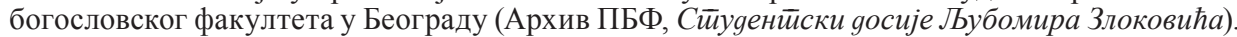
Реч је о потоњем епископу горњокарловачком Симеону (1951-1990). $185-188$.

33 Љ. Злоковић, „Ђоко М. Слијепчевић: Стеван Стратимировић”, Свейосавље 3-4 (1936),

${ }^{34}$ С. Станојевић, Боко М. Слијейчевић, 470.

35 Исто.

36 Љ. Злоковић, Боко М. Слијеиччевић, 186. 
политу, сагледавајући сложену епоху и конкретне историјске прилике у којима је деловао. Посебно је похвалио одељке посвећене митрополитовом односу према Вуку Караџићу, истичући да је аутор овом питању приступио објективније од дотадашњих истраживача. ${ }^{37}$

Наредне 1937. године приказ је у Јуйословенском истиориском часойису објавио Јован Радонић. ${ }^{38}$ Он се придружио претходно исказаним ставовима о томе да је Слијепчевићево дело допринело попуњавању празнине у српској историографији. Сматрао је да „књига г. Слијепчевића иде међу добре ствари које су до сада написане о Стратимировићу". ${ }^{39}$ Најслабије поглавље књиге било је уводно, посвећено митрополитовим биографским подацима. Радонић је овде уочио и неке фактографске грешке, које је у приказу исправио. $40 \mathrm{y}$ осталим поглављима Слијепчевић је донео „пуно тога новога”. ${ }^{41}$ Његово кориговање дотадашњих неповољних судова о Стратимировићу оцењено је као научно утемељено, посебно у сегменту везаном за наводну митрополитову аутократију у погледу несазивања сабора и за његов однос према Вуку Караџићу. Радонић жали што Слијепчевић није унео и поглавље о књижевном раду митрополита ради потпуности монографије, па констатује: „Да је то унесено у ову добру књигу личност заслужнога митрополита била би објашњена са сваке стране”. И без тога књига је добра и ,један од најбољих радова о митрополиту Стратимировићу". 42

Исте године када и Радонићев приказ појавила се студија Николе Радој-

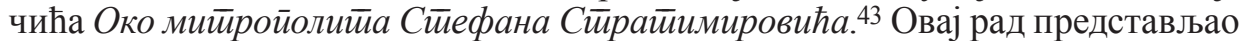
је наставак дотадашњих Радојчићевих истраживања о митрополиту, посебно његовог излагања у Матици српској, почетком 1936. године. ${ }^{44}$ Желео је да допуни ово излагање, а додатни подстицај му је представљало појављивање Слијепчевићевог дела. У студији је размотрено неколико питања везаних за митрополита Стефана Стратимировића: о изворима и литератури о њему, о његовим родитељима, борби против уније, поучним песмама, мемоару упућеном руском цару, просветној делатности, чланству у слободним зидарима и писмима. Сва поменута питања размотрена су и у светлу научних резултата изнетих у Слијепчевићевом делу. Радојчић је у Слијепчевићевом делу, пре свега, видео користан нацрт биографије митрополита Стефана Стратимировића, који треба да укаже на проблеме у дотадашњим проучавањима и отвори нове перспективе. Целовита биографија могућа је тек после низа мањих специјалних студија. Иако је, на неки начин, одрекао целовитост Слијепчевићевог дела, признао га је корисним за науку. То је „одличан подсетник

37 Исто, 187.

38 Ј. Радонић, „Ђоко М. Слијепчевић, Стеван Стратимировић, Београд 1936”, Jуі̄ословенски истиориски часойис 1-4 (1937), 385-388.

39 Исто, 386.

40 Исто, 386-387.

${ }^{41}$ Исто, 387.

42 Исто, 388.

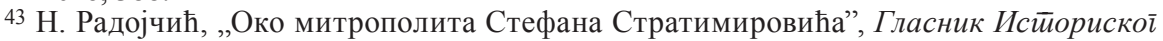
gрушитва у Новом Саяу 2 (1937), 161-179.

${ }^{44}$ Н. Радојчић, „Митрополит Стефан Стратимировић”, Лейойис Майище срӣске 1 (1936), 40-60. 
за решена и нерешена питања из живота и рада великога митрополита". 45 Сматрао је, ипак, да би боље било да се аутор као богослов ограничио само на један сегмент Стратимировићеве делатности и то онај црквени. Радојчић је изнео озбиљне приговоре у вези са архивском грађом која је коришћена у дисертацији. Некоришћење бечких, пештанских и руских архива, а посебно непотпуно коришћење домаћих архива били су важни разлози Радојчићеве оцене о нецеловитости дела. Критиковао је некоришћење конзисторијалних архива у бившој Карловачкој митрополији, посебно централног у Сремским Карловцима, архива Карловачке гимназије и богословије, епархијских и манастирских архива. Критиковао је често неправилно навођење коришћене периодике и литературе. ${ }^{46}$ У сваком од одељака своје студије Радојчић је указивао на пропусте и исправљао фактографске грешке у Слијепчевићевом делу. Сматрао је да је Слијепчевић могао да мање панегирично приказује Стратимировића, да дубље упозна русофилску позадину његових ставова, да читаоце упозна са његовим поучним песмама. Као квалитет дисертације истакао је добро коришћење Стратимировићевих писама. У Слијепчевићевој дисертацији видео је још један аргумент у корист објављивања Стратимировићеве преписке. ${ }^{47}$ И поред оштре критике, својствене Николи Радојчићу као водећем историчару српске историографије, призната је научна вредност Слијепчевићевог дела. Оценио је да дела попут овог „могу науци учинити сјајних услуга". 48

Слијепчевићева дисертација била је подстицај и за Радослава Грујића да 1939. године у Боїословљу објави рад „Стратимировићево архипастирство. Поводом докторске дисертације Ђоке М. Слијепчевића". 49 Годину дана раније (1938), у реферату за Слијепчевићев избор за приватног доцента на Катедри за Историју Цркве на Православном богословском факултету, Грујић се кратко осврнуо на његову дисертацију истакавши да је „научна критика запазила и добро примила његову дисертацију о митрополиту Стевану Стратимировићу". 50 У раду објављеном у Боіослловљу Грујић је желео да допуни Слијепчевићево истраживање у сегменту везаном за Стратимировићево архипастирство исказано кроз духовно руковођење паством у његовој Сремској архидијецези, посебно на почетку његове управе. Извор је нашао у Стратимировићевим архипастирским посланицама које су сачуване у циркуларним протоколима парохија бивше Карловачке митрополије. Сматрао је да је то важан сегмент митрополитове делатности о којој Слијепчевић није писао. Представио је и анализирао четири архипастирске посланице, чији је интегрални текст дао у прилогу рада. ${ }^{51}$ Наредне, 1940. године, Грујић је опет писао реферат за Слијепчевића, овога пута за универзитетског доцента на Катедри за Историју Цркве на Православном богословском факултету. Том

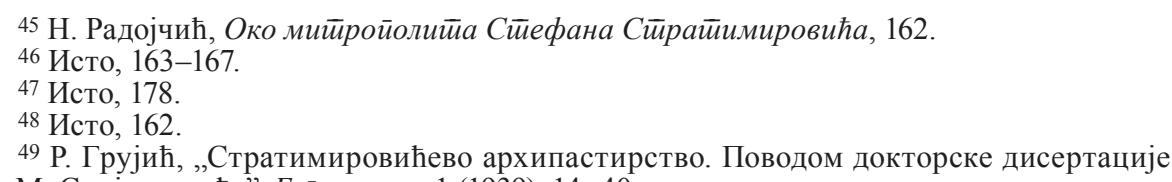

Ђоке М. Слијепчевића", Боіоословље 1 (1939), 14-40.

50 Архив ПБФ, Професорски яосије Бока М. Слијейчевића.

${ }^{51}$ Р. Грујић, Сйрайимировићево архийастиирстиво, 31-40. 
приликом је поново истакао да је његова дисертација „примљена у нашој науци повољно", наводећи као пример приказ Станоја Станојевића. Навео је да су „повољне реферате о њој, уз извесне примедбе и допуне, дали и проф. Никола Радојчић и овде потписани". 52

$$
\text { * } \quad * \quad *
$$

Ђоко Слијепчевић је докторском дисертацијом посвећеном митрополиту карловачком Стефану Стратимировићу озбиљно закорачио у српску научну заједницу. О томе сведоче осврти главних српских историчара међуратног периода. Дело о митрополиту Стратимировићу чини део својеврсне Слијепчевићеве трилогије посвећене истакнутим личностима српске црквене историје. Започета делом о патријарху Пајсију Јањевцу, продужена дисертацијом о Стратимировићу, ова трилогија закључена је монографијом о митрополиту Михаилу Јовановићу, објављеном у Минхену 1980. године. ${ }^{53}$ Значајни делови дисертације уграђени су у најважније Слијепчевићево дело Иситорију Срйске Православне Цркве. ${ }^{54}$

У Светосавској беседи одржаној у Матици српској 26. јануара 2007. године Славко Гавриловић је, уз Димитрија Руварца, Николу Радојчића и Теодору Мајицу Петровић, истакао Ђока Слијепчевића као мериторног биографа митрополита Стефана Стратимировића. ${ }^{55}$ Његова докторска дисертација, одбрањена на Православном богословском факултету у Београду 1936. године, и даље представља једно од главних дела српске историографије о овом знаменитом карловачком митрополиту.

ORIGINAL SCIENTIFIC PAPER

Prof. VLADISLAV PUZOVIĆ, PhD

University of Belgrade

Faculty of Orthodox Theology

Mije Kovačevića 11b, Belgrade, Serbia

E mail: vpuzovic@bfspc.bg.ac.rs

\section{ON ĐOKO SLIJEPČEVIĆ'S DOCTORAL THESIS}

SUMMARY: Đoko Slijepčević's doctoral thesis, dedicated to the Metropolitan of Karlovci Stefan Stratimirović, was defended at the Faculty of Orthodox Theology in Belgrade in 1936. It is important in many aspects. It was the first doctoral thesis defended at the aforementioned faculty. Its author was one of the most prominent Serbian Church historians of the

52 Архив ПБФ, Професорски досије Ђока М. Слијейчевића.

53 Ђ. Слијепчевић, Михаило, архиейиской беоіраяски и митиройолий Србије, Минхен 1980.

54 У другом тому Ист̄орије Срйске Православне Цркве, објављеном у Минхену 1966. године, поглавље посвећено митрополиту Стефану Стратимировићу преузето је знатним делом из докторске дисертације.

55 С. Гавриловић, „Митрополит Стефан Стратимировић. Поводом 250-годишњице рођења", Летиойис Майиие срйске 3 (2007), 395. 
$20^{\text {th }}$ century. This thesis, later published as a monograph, was the first comprehensive and systematic study dedicated to the renowned Metropolitan who, for almost half a century, governed the Metropolitanate of Karlovci. Slijepčević wrote the thesis under the mentorship of Stevan Dimitrijević, the first History professor of the Serbian Orthodox Church at the Faculty of Orthodox Theology in Belgrade. Here, he presented the key aspects of Stratimirović's work, mostly according to unpublished archival materials. The appearance of Slijepčević's work aroused great interest in the Serbian scientific community, which can be seen in the overviews and reviews of the most prominent Serbian historians in the period between the two World Wars. They recognised the dissertation as a reference work enabling Slijepčević to seriously enter the Serbian scientific community. This work, which today represents a biblographic rarity, has kept its scientific reference.

KEYWORDS: Đoko Slijepčević, Faculty of Orthodox Theology in Belgrade, Doctoral Thesis, Metropolitan of Karlovci Stefan Stratimirović, Stevan Dimitrijević, Serbian Historiography 